\title{
Genetic relationships of alternative somatic cell count traits with milk yield, composition and udder type traits in Italian Jersey cows
}

\author{
Tania Bobbo $^{1}$ (D) | Chiara Roveglia ${ }^{1}$ | Mauro Penasa $^{1}$ (D) | Giulio Visentin ${ }^{2}$ | \\ Raffaella Finocchiaro $^{2}$ | Martino Cassandro ${ }^{1}$
}

${ }^{1}$ Department of Agronomy, Food, Natural Resources, Animals and

Environment, University of Padova, Legnaro, Padova, Italy

${ }^{2}$ Associazione Nazionale Allevatori della Razza Frisona e Jersey Italiana (ANAFIJ),

Cremona, Italy

\section{Correspondence}

Tania Bobbo, Department of Agronomy, Food, Natural Resources, Animals and Environment, University of Padova, Legnaro, Padova, Italy.

Email: tania.bobbo@unipd.it

\section{Funding information}

"Latteco project", sottomisura 10.2 of the PSRN-Biodiversity 2014-2020; University of Padova, Grant/Award Number: DOR1899548/18

\begin{abstract}
The aim of this study was to estimate genetic associations between alternative somatic cell count (SCC) traits and milk yield, composition and udder type traits in Italian Jersey cows. Alternative SCC traits were test-day (TD) somatic cell score (SCS) averaged over early lactation (SCS_150), standard deviation of SCS of the entire lactation (SCS_SD), a binary trait indicating absence or presence of at least one TD SCC $>400,000$ cells $/ \mathrm{ml}$ in the lactation (Infection) and the ratio of the number of TD SCC $>400,000$ cells $/ \mathrm{ml}$ to total number of TD in the lactation (Severity). Heritabilities of SCC traits, including lactation-mean SCS (SCS_LM), ranged from 0.038 to 0.136 . Genetic correlations between SCC traits were moderate to strong, with very few exceptions. Unfavourable genetic associations between milk yield and SCS_SD and Infection indicated that high-producing cows were more susceptible to variation in SCC than low-producing animals. Cows with deep udders, loose attachments, weak ligaments and long teats were more susceptible to an increase of SCC in milk. Overall, results suggest that alternative SCC traits can be exploited to improve cow's resistance to mastitis in Italian Jersey breed.
\end{abstract}

KEYWORDS

dairy cattle, genetic selection, mastitis, somatic cell score, udder conformation

\section{1 | INTRODUCTION}

A strategy to improve genetic selection for disease resistance is to exploit the information routinely collected during milk recording procedures. A clear example is given by somatic cell count (SCC), which is recorded in many countries and is the most common indicator of udder health worldwide. Indeed, log-transformed SCC (SCS) is known to be strongly genetically associated with clinical mastitis, thus explaining why test-day (TD) SCS and lactation-mean SCS have been historically included in selection programmes to improve mastitis resistance (Martin, Barkema, Brito, Narayana, \& Miglior, 2018). However, TD SCS and lactation-mean SCS are not very informative on the dynamic of the infection. Therefore, alternative traits derived from TD SCC have been explored to better describe SCC variation within lactation and to genetically improve resistance to mastitis (de Haas, Ouweltjes, ten Napel, Windig, \& de Jong, 2008; Koeck, Miglior, Kelton, \& Schenkel, 2012a; Urioste, Franzén, \& Strandberg, 2010). Recently, Bobbo, Penasa, Finocchiaro, Visentin, and Cassandro (2018) have investigated phenotypic and genetic aspects of four alternative SCC traits and concluded that a combination of those traits was a good predictor of SCC variation during lactation in Holstein cows. Results of the above-mentioned study contributed to define a novel udder health index in the Italian Holstein breed (Finocchiaro et al., 2018), in support of the current one which is based on TD SCS. 
Among its responsibilities, the National Association of Holstein and Jersey Breeders (ANAFIJ, Cremona, Italy) is in charge of the genetic evaluation of the Italian Jersey, a dairy breed characterized by lower milk production than Holstein, but with optimal milk composition and coagulation ability (Roveglia et al., 2019; Stocco, CipolatGotet, Bobbo, Cecchinato, \& Bittante, 2017; Visentin et al., 2017a). Given the favourable milk composition and technological properties, Jersey cows are often reared in mixed herds with Holsteins. At first, the national selection index of the Jersey breed included only production traits (Biffani, Samoré, \& Canavesi, 2003). In 2005, three udder type traits were added to the index, namely fore udder attachment, udder support and udder depth. However, no selection for somatic cell traits in milk has been performed so far. Therefore, the aim of this study was to define alternative SCC traits, derived from routine TD recording system, in Italian Jersey cows and to estimate their genetic relationships with milk yield, composition and udder type traits. Findings of this work will provide additional information to develop a udder health index aimed to improve resistance to mastitis in Italian Jersey breed.

\section{2 | MATERIALS AND METHODS}

\section{1 | Data editing}

The original database of TD records of Jersey cows provided by ANAFIJ was edited to include only first-parity cows between 5 and 305 days in milk (DIM), sampled between 2005 and 2016. Following Bobbo et al. (2018), cows with at least 5 TD records (of which at least 3 collected from 5 to 150 DIM) were considered. In addition, only cows with the first TD within 60 days after calving and with an interval between two consecutive TD lower than 70 days were retained. After editing, 101,420 TD milk yield (kg/ day), composition and SCC (cells/ml) records of 12,754 Jersey cows in 428 herds were available for statistical analysis. Milk composition traits included fat, protein, casein and lactose percentages, and milk urea nitrogen $(\mathrm{mg} / \mathrm{dl})$, which were determined using midinfrared spectroscopy. For each cow, TD milk yield and composition traits were averaged to compute lactation-mean milk yield, fat, protein, casein and lactose percentages, and milk urea nitrogen. As reported in Bobbo et al. (2018), TD SCC data were logtransformed to TD SCS (Ali \& Shook, 1980), and lactation-mean SCS (SCS_LM) was calculated. Alternative SCC traits were as follows: TD SCS averaged over early lactation, that is from 5 to 150 DIM (SCS_150); standard deviation of SCS of the entire lactation (SCS_SD); a binary trait indicating absence (0) or presence (1) of at least one TD SCC > 400,000 cells/ml in the lactation (Infection); and the ratio of the number of TD SCC $>400,000$ cells $/ \mathrm{ml}$ to total number of TD in the lactation (Severity). The SCC threshold of 400,000 cells $/ \mathrm{ml}$ was chosen to identify potential mastitis events as it represents the limit applied by the European Union for bulk milk destined to human consumption (Reg. EU 853/2004). In addition to lactation-mean traits, mature equivalent (ME) milk, fat and protein yields were retrieved from the database of the Italian
Breeders Association (AIA, Rome, Italy). These traits represent the cumulative 305-day milk, fat and protein yield adjusted for age at calving and month of calving. Furthermore, information on the following udder type traits scored on a 1-50 points linear scale was provided by ANAFIJ:

fore udder attachment: strength of the attachment of the fore udder

to the body wall $(1=$ loose, $50=$ tight $)$;

rear udder height: distance between the bottom of the vulva and the milk secreting tissue ( 1 = low, 50 = high);

rear udder width: width of the high part of udder ( $1=$ narrow, 50 = wide);

udder support: depth of cleft of the udder, measured at the base of the rear udder ( 1 = weak, 50 = strong);

udder depth: measure of the depth of udder floor relative to the hock $(1=$ deep, 50 = shallow);

front teat placement: position of the front teats from centre of quarter, viewed from the rear $(1=$ wide, 50 = close $)$;

front teat length: length of the front teats from the base to the end of the teat $(1=$ short, 50 = long).

Only evaluations performed between 5 and 305 DIM on cows from 18 to 42 months of age at calving were considered $(n=9,482)$.

\section{2 | Statistical analysis}

A preliminary investigation of the non-genetic sources of variation of SCS_LM and alternative SCC traits was conducted by fitting linear mixed or logistic regression models in SAS (SAS Institute Inc., Cary, NC) depending on trait considered (binary or continuous), including year of calving (13 levels, from 2004 to 2016), season of calving (4 levels, winter: December, January, February; spring: March, April, May; summer: June, July, August; autumn: September, October, November), number of TD (6 levels, from 5 to 10) and milk yield (3 levels, based on mean $\pm 1 S D$ ) as fixed effects, and herd (428 levels) as random effect.

A 5-trait animal model was then applied to a subset of 8,124 Jersey cows to estimate heritability of and genetic correlations between SCC traits. For each trait, the model was:

$$
y_{i j k}=\mu+\mathrm{HYS}_{i}+\mathrm{ntd}_{j}+\text { Animal }_{\mathrm{k}}+e_{i j k} \text {, }
$$

where $y_{i j k}$ represents SCS_LM, SCS_150, SCS_SD, Infection, and Severity; $\mu$ represents the overall means; $\mathrm{HYS}_{i}$ is the fixed effect of the ith herd-year-season of calving ( $i=650$ levels); $n \mathrm{td}_{j}$ is the fixed effect of the $j$ th number of TD ( $j=6$ levels); Animal $_{k}$ is the random additive genetic effect of the $k$ th animal ( $k=26,080$ individuals) and $e_{i j k}$ is the random residual.

Bivariate animal models were run using a subset of 5,601 cows to estimate heritability of lactation-mean milk yield and composition traits, and their genetic correlations with SCC traits. The effects included in the models were those reported above: HYS (381 levels) and number of TD (6 levels) as fixed effects, and additive genetic animal $(18,902$ individuals) as random effect. Since the current selection 
index of Italian Jersey breed considers the estimated breeding values of ME milk and protein yields, a supplementary statistical analysis was carried out using a subset of 5,574 cows to estimate genetic associations between ME yields and SCC traits through a series of bivariate animal models. Mature equivalent yields were adjusted for herd-year-season of calving (381 levels) and additive genetic animal (18,902 individuals) effects.

Finally, bivariate animal models were performed using a subset of 6,195 cows to estimate heritability of udder type traits, and genetic correlations between SCC traits and udder type traits. The model for SCC traits included the fixed effects of HYS (489 levels) and number of TD ( 6 levels), and the random effect of additive genetic animal (20,376 individuals). The model for each udder type trait was as follows:

$$
y_{i j k l m}=\mu+\mathrm{HYC}_{i}+\text { Season }_{j}+\mathrm{DIM}_{k}+\mathrm{Age}_{l}+\text { Animal }_{m}+e_{i j k l m},
$$

where $y_{i j k l m}$ represents the udder type trait; $\mu$ represents the overall mean; $\mathrm{HYC}_{i}$ is the fixed effect of the ith herd-year-classifier ( $i=241$ levels); Season $n_{j}$ is the fixed effect of the $j$ th season of evaluation ( $j=4$ levels, winter: December, January, February; spring: March, April, May; summer: June, July, August; autumn: September, October, November); $D_{1} M_{k}$ is the fixed effect of the $k$ th class of DIM at scoring ( $k=10$ levels of 30 days each); Age, is the fixed effect of the Ith class of age at calving $(I=9$ levels, the first being a class from 18 to 22 months, followed by 7 classes of 2 months each, and the last being a class from 36 to 42 months); Animal $_{m}$ is the random additive genetic effect of the $m$ th animal ( $k=20,376$ individuals) and $e_{i j k l m}$ is the random residual.

The same criteria of data editing (inclusion of cows with known sire and dam and at least 5 observations for each HYS level) were adopted for the extraction of the subsets described above. Moreover, at least three observations for each HYC level were required for udder type traits. Pedigree information was provided by ANAFIJ and included cows with phenotypic records and all their ancestors up to six generations back. Variance components and heritability of lactation-mean milk yield and composition, ME yields and udder type traits were the average of the values obtained from the bivariate analyses. All the genetic analyses were performed using the software VCE6 (Neumaier \& Groeneveld, 1998), through restricted maximum likelihood (REML) procedures.

\section{3 | RESULTS}

\section{1 | Descriptive statistics}

Lactation-mean SCS and SCS_150 averaged 3.09 and 3.01, respectively (Table 1). Standard deviation of SCS ranged from 0.11 to 4.26 , with a mean of 1.10 . About $43 \%$ of the cows had at least one TD $\mathrm{SCC}>400,000$ cells $/ \mathrm{ml}$ during the lactation (Infection) and the ratio of the number of TD SCC $>400,000$ cells $/ \mathrm{ml}$ to total number of TD (Severity) averaged 0.11. Milk yield of Jersey cows averaged $19.46 \mathrm{~kg} /$ day (Table 1). Means of fat, protein, casein and lactose contents were $5.03 \%, 3.97 \%, 3.08 \%, 4.85 \%$, respectively, and milk urea nitrogen averaged $23.56 \mathrm{mg} / \mathrm{dl}$. Mature equivalent milk, fat and protein production was $7,088 \mathrm{~kg}, 354 \mathrm{~kg}$ and $280 \mathrm{~kg}$, respectively. Udder type traits averaged from 22.38 (front teat length) to 30.16 (rear udder width) and their coefficient of variation ranged from $20 \%$ (rear udder width) to $27 \%$ (fore udder attachment, udder depth and front teat length) (Table 1). The subsets used for the genetic analysis were representative of the edited dataset, as the descriptive statistics of the traits (Table 2) were comparable with those reported in Table 1.

\subsection{Genetic variation and heritability}

Fixed effects (year and season of calving, number of TD and milk production) included in the models for phenotypic analysis of alternative SCC traits were significant in explaining the variation of these traits $(p<0.05)$. A remarkable result was that SCS_LM tended to increase across years of calving (Figure 1). In particular, according to Tukey multiple comparison test, SCS_LM was lower in the years from 2004 to 2008 compared with later years (i.e. 2010, 2013 and 2014). Variance components and heritability of SCC traits, milk yield and composition, ME production and udder type traits are reported in Table 2. All traits had coefficients of additive genetic variation below $13 \%$, with the only exception of Infection (26.5\%) and Severity (38.2\%). Medium to high heritability was assessed for lactation-mean milk yield and composition traits, and ME yields, with estimates from $0.271 \pm 0.035$ (milk urea nitrogen) to $0.610 \pm 0.034$ (fat percentage). Heritability of SCC traits and udder type traits was smaller than that of milk production and composition, ranging from $0.038 \pm 0.015$ (SCS_SD) to $0.136 \pm 0.022$ (SCS_LM) for SCC traits and from $0.073 \pm 0.022$ (rear udder width) to $0.190 \pm 0.028$ (udder depth) for udder type traits.

\section{3 | Correlations}

\subsubsection{Correlations between SCC traits}

Genetic and phenotypic correlations between SCC traits were estimated using a 5-trait analysis (Table 3 ). Strong genetic correlations were obtained between SCS_LM and SCS_150 (0.986 \pm 0.014$)$, and between Infection and Severity (0.989 \pm 0.014$)$. Genetic correlations between other SCC traits ranged from $0.521 \pm 0.171$ (SCS_SD and Severity) to $0.846 \pm 0.055$ (SCS_LM and Severity), except for the null genetic association of SCS_SD with SCS_LM and SCS_150. Overall, phenotypic correlations between SCC traits were lower than their genetic counterparts.

\subsubsection{Correlations of SCC traits with lactation- mean milk yield and composition, and ME milk production traits}

Results from bivariate analyses showed unfavourable genetic correlations of lactation-mean milk yield with SCS_SD $(0.566 \pm 0.246)$ and Infection $(0.374 \pm 0.213)$ (Table 4). Similar results were 
TABLE 1 Number of records ( $n$ ), mean, standard deviation (SD), minimum and maximum of lactation-mean somatic cell score (SCS_LM), alternative somatic cell count (SCC) traits, lactation-mean milk yield and composition, mature equivalent (ME) production traits and udder type traits of first-parity Jersey cows

\begin{tabular}{|c|c|c|c|c|c|}
\hline Trait & $n$ & Mean & $S D$ & Minimum & Maximum \\
\hline SCS_LM & 12,754 & 3.09 & 1.12 & -0.96 & 8.42 \\
\hline \multicolumn{6}{|l|}{ Alternative SCC traits } \\
\hline SCS_150 & 12,732 & 3.01 & 1.22 & -1.22 & 9.03 \\
\hline SCS_SD & 12,754 & 1.10 & 0.59 & 0.11 & 4.26 \\
\hline Infection & 12,754 & 0.43 & - & 0 & 1 \\
\hline Severity & 12,754 & 0.11 & 0.18 & 0 & 1 \\
\hline Milk yield (kg/day) & 12,754 & 19.46 & 4.15 & 4.32 & 40.55 \\
\hline \multicolumn{6}{|l|}{ Milk composition } \\
\hline Fat (\%) & 12,754 & 5.03 & 0.65 & 2.46 & 7.71 \\
\hline Protein (\%) & 12,754 & 3.97 & 0.28 & 2.91 & 4.95 \\
\hline Casein (\%) & 8,259 & 3.08 & 0.25 & 2.18 & 5.00 \\
\hline Lactose (\%) & 10,781 & 4.85 & 0.13 & 3.96 & 5.28 \\
\hline $\begin{array}{l}\text { Milk urea nitrogen } \\
(\mathrm{mg} / \mathrm{dl})\end{array}$ & 8,135 & 23.56 & 6.30 & 2.00 & 45.42 \\
\hline \multicolumn{6}{|l|}{ ME production traits $(\mathrm{kg})$} \\
\hline Milk yield & 12,541 & 7,088 & 1,551 & 1,289 & 13,997 \\
\hline Fat yield & 12,541 & 354 & 75 & 63 & 834 \\
\hline Protein yield & 12,541 & 280 & 60 & 51 & 587 \\
\hline \multicolumn{6}{|l|}{ Udder type traits (score) } \\
\hline $\begin{array}{l}\text { Fore udder } \\
\text { attachment }\end{array}$ & 9,482 & 23.66 & 6.39 & 1.00 & 45.00 \\
\hline Rear udder height & 9,482 & 26.38 & 6.04 & 2.00 & 48.00 \\
\hline Rear udder width & 9,482 & 30.16 & 5.93 & 2.00 & 49.00 \\
\hline Udder support & 9,482 & 27.47 & 5.98 & 1.00 & 49.00 \\
\hline Udder depth & 9,482 & 25.59 & 6.82 & 2.00 & 50.00 \\
\hline Front teat placement & 9,482 & 23.37 & 5.29 & 1.00 & 45.00 \\
\hline Front teat length & 9,482 & 22.38 & 6.03 & 2.00 & 48.00 \\
\hline
\end{tabular}

SCS_150: average SCS in early lactation (5-150 days in milk); SCS_SD: standard deviation of SCS of the entire lactation; Infection: a binary trait indicating absence (0) or presence (1) of at least one test-day SCC above 400,000 cells/ml; Severity: ratio of the number of test-day SCC above 400,000 cells $/ \mathrm{ml}$ to total number of test-days in the lactation. obtained considering ME milk production, which was characterized by positive genetic correlations with SCS_SD $(0.484 \pm 0.224)$ and Infection (0.339 \pm 0.199$)$. Phenotypic and genetic correlations of SCC traits with lactation-mean fat, protein and casein percentages were generally very weak $(0.004-0.200$, in absolute value). Lactose percentage was weakly or moderately negatively correlated with all SCC traits, both at genetic and phenotypic level $(-0.360 \pm 0.181$ to $-0.064 \pm 0.166)$. Lactationmean milk urea nitrogen was positively genetically associated with SCS_LM (0.184 \pm 0.125$)$, SCS_150 (0.221 \pm 0.132$)$ and Severity $(0.186 \pm 0.176)$, and negatively genetically associated with SCS_SD $(-0.278 \pm 0.182)$ and Infection $(-0.232 \pm 0.208)$. Mature equivalent fat and protein yields were positively genetically correlated with SCS_SD, Infection and Severity, with estimates from $0.213 \pm 0.176$ (ME protein yield and Severity) to $0.577 \pm 0.221$ (ME protein yield and SCS_SD).

\subsection{3 | Correlations between SCC traits and udder type traits}

Weak genetic correlations were estimated between SCC traits and udder type traits (Table 5). Fore udder attachment was negatively associated with SCS_150 $(-0.209 \pm 0.152)$ and SCS_SD $(-0.190 \pm 0.198)$, and udder support was negatively correlated with SCS_LM $(-0.164 \pm 0.187)$ and SCS_150 $(-0.145 \pm 0.202)$. Negative genetic correlations were assessed between udder depth and SCC traits, ranging from $-0.304 \pm 0.176$ (udder depth and SCS_SD) to $-0.189 \pm 0.143$ (udder depth and Severity). Positive genetic correlations were estimated between front teat length and SCS_SD (0.306 \pm 0.210$)$, Infection $(0.233 \pm 0.199)$ and Severity $(0.267 \pm 0.182)$. Moreover, positive genetic associations were obtained between rear udder height and Infection (0.206 \pm 0.220$)$, and rear udder width and Infection (0.143 \pm 0.233$)$. 


\begin{tabular}{|c|c|c|c|c|c|}
\hline Trait & Mean (SD) & $\sigma_{a}^{2}$ & $\sigma_{e}^{2}$ & $\mathrm{CV}_{\mathrm{a}}(\%)$ & $h^{2}(\mathrm{SE})$ \\
\hline SCS_LM & $3.10(1.09)$ & 0.135 & 0.857 & 11.8 & $0.136(0.022)$ \\
\hline \multicolumn{6}{|l|}{ Alternative SCC traits } \\
\hline SCS_150 & $3.04(1.18)$ & 0.136 & 1.068 & 12.1 & $0.113(0.021)$ \\
\hline SCS_SD & $1.10(0.58)$ & 0.011 & 0.272 & 9.4 & $0.038(0.015)$ \\
\hline Infection & 0.43 & 0.013 & 0.208 & 26.5 & $0.058(0.017)$ \\
\hline Severity & $0.11(0.17)$ & 0.002 & 0.024 & 38.2 & $0.066(0.017)$ \\
\hline Milk yield (kg/day) & $19.60(4.16)$ & 3.170 & 5.414 & 9.1 & $0.369(0.038)$ \\
\hline \multicolumn{6}{|l|}{ Milk composition } \\
\hline Fat (\%) & $4.89(0.59)$ & 0.160 & 0.102 & 8.2 & $0.610(0.034)$ \\
\hline Protein (\%) & $3.96(0.27)$ & 0.034 & 0.022 & 4.6 & $0.604(0.034)$ \\
\hline Casein (\%) & $3.09(0.24)$ & 0.018 & 0.022 & 4.3 & $0.444(0.036)$ \\
\hline Lactose (\%) & $4.86(0.13)$ & 0.007 & 0.007 & 1.7 & $0.486(0.037)$ \\
\hline $\begin{array}{l}\text { Milk urea nitrogen } \\
\text { (mg/dl) }\end{array}$ & 24.39 (4.99) & 2.585 & 6.961 & 6.6 & $0.271(0.035)$ \\
\hline \multicolumn{6}{|c|}{ ME production traits $(\mathrm{kg})$} \\
\hline Milk yield & $\begin{array}{l}7,237 \\
(1,585)\end{array}$ & 478,704 & 841,866 & 9.6 & $0.362(0.036)$ \\
\hline Fat yield & $352(75)$ & 851 & 2,053 & 8.3 & $0.293(0.038)$ \\
\hline Protein yield & $286(64)$ & 563 & 1,203 & 8.3 & $0.319(0.036)$ \\
\hline \multicolumn{6}{|c|}{ Udder type traits (score) } \\
\hline $\begin{array}{l}\text { Fore udder } \\
\text { attachment }\end{array}$ & $23.44(6.39)$ & 5.666 & 31.181 & 10.2 & $0.154(0.027)$ \\
\hline Rear udder height & $26.03(6.11)$ & 2.823 & 29.994 & 6.5 & $0.086(0.023)$ \\
\hline Rear udder width & $30.35(5.80)$ & 1.905 & 24.175 & 4.5 & $0.073(0.022)$ \\
\hline Udder support & $27.57(5.73)$ & 2.824 & 27.219 & 6.1 & $0.094(0.027)$ \\
\hline Udder depth & $25.86(6.70)$ & 7.216 & 30.688 & 10.4 & $0.190(0.028)$ \\
\hline $\begin{array}{l}\text { Front teat } \\
\text { placement }\end{array}$ & $23.39(5.42)$ & 2.206 & 24.448 & 6.3 & $0.083(0.021)$ \\
\hline Front teat length & $21.84(6.26)$ & 2.847 & 28.141 & 7.7 & $0.092(0.022)$ \\
\hline
\end{tabular}

TABLE 2 Descriptive statistics, additive genetic variance $\left(\sigma_{a}^{2}\right)$, residual variance $\left(\sigma_{e}^{2}\right)$, coefficient of additive genetic variation $\left(\mathrm{CV}_{\mathrm{a}}\right)$ and heritability $\left(h^{2}\right.$; $\mathrm{SE}$ within parentheses) of lactation-mean somatic cell score (SCS_LM), alternative somatic cell count (SCC) traits, lactationmean milk yield and composition, mature equivalent (ME) production traits and udder type traits of first-parity Jersey cows

SCS_150: average SCS in early lactation (5-150 days in milk); SCS_SD: standard deviation of SCS of the entire lactation; Infection: a binary trait indicating absence (0) or presence (1) of at least one test-day SCC above 400,000 cells/ml; Severity: ratio of the number of test-day SCC above $400,000 \mathrm{cell} / \mathrm{s} / \mathrm{ml}$ to total number of test-days in the lactation.

\section{4 | DISCUSSION}

A strategy to decrease the incidence of mastitis in the farm is to breed for resistance to the disease (Ruegg, 2017). To this purpose, exploiting all information currently recorded in the framework of routine milk recording system is of great importance, given the difficulty of implementing direct recording of disease. In this study we defined four alternative SCC traits, derived from TD data routinely collected at monthly intervals, and estimated their genetic relationships with lactation-mean milk yield and composition traits, ME milk, fat and protein yields, and udder type traits in Jersey cows. Alternative SCC traits, currently included in a novel udder health index of Italian Holsteins (Finocchiaro et al., 2018), could possibly be considered in the national selection index of the Jersey breed, to select cows with improved resistance to mastitis. Figure 1 provides further evidence for the need of inclusion of SCC in the selection index. In fact, in the last years there has been an increase in SCS_LM, possibly as a result of selection initially based on milk production only, suggesting that current selection for udder type traits alone is not enough to improve udder resistance to mastitis.

\section{1 | Heritability}

\subsection{1 | Alternative SCC traits}

To the best of our knowledge, this is the first study dealing with alternative SCC traits in Jersey breed. Thus, our results could be compared only with the existing literature on Holsteins. In this study, alternative SCC traits were heritable and expressed exploitable additive genetic variation (Table 2), implying the feasibility of their inclusion in genetic selection programmes for mastitis resistance. Estimates of heritability of average SCS in early lactation (from 5 


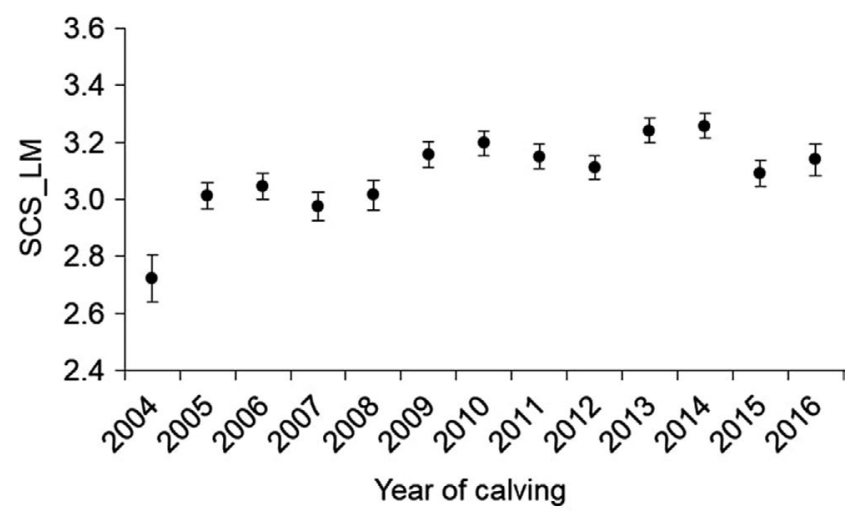

FIGURE 1 Least squares means of lactation-mean somatic cell score (SCS_LM) across years of calving of first-parity Jersey cows $(n=12,754)$

to 150 DIM) were comparable with those (0.08-0.11) reported for Holstein cows (Bobbo et al., 2018; de Haas et al., 2008; Windig et al., 2010). Heritability of SCS_SD, a trait which describes SCC variation during lactation and identified by Green et al. (2004) as a good predictor of clinical mastitis, was in agreement with estimates of 0.03 and 0.04 reported by Koeck et al. (2012a) and Bobbo et al. (2018) respectively. According to de Haas et al. (2008), Urioste et al. (2010) and Koeck et al. (2012a), traits that express an excess of TD SCC above a predefined threshold are potential indicators of udder infection and thus relevant for indirect selection against mastitis. Heritability of Infection and Severity, both associated with TD SCC greater than 400,000 cells $/ \mathrm{ml}$, was about 0.06 (Table 2), similar to the results of Bobbo et al. (2018) for Italian Holsteins (0.057 and 0.047 for Infection and Severity, respectively).

\subsection{2 | Lactation-mean milk yield and composition, ME production and udder type traits}

In this study, heritabilities of lactation-mean milk yield and composition, and ME yields were moderate to high (Table 2), and generally in agreement with previous results in the same breed. For instance Campos, Wilcox, Becerril, and Diz (1994) reported heritability estimates of $0.327,0.526$ and 0.662 for milk yield, fat percentage and protein percentage, respectively. Roman, Wilcox, and Martin (2000) estimated heritabilities of 0.26 for milk yield and 0.53 for fat and protein percentages in first-parity Jerseys, and Missanjo, Imbayarwo-Chikosi, and Halimani (2013) reported heritabilities of $0.38,0.47$ and 0.49 for milk yield, fat percentage and protein percentage, respectively.

Sneddon, Lopez-Villalobos, Hickson, and Shalloo (2012) assessed heritabilities of 0.50 for milk yield, and $0.33,0.58$ and 0.64 , for fat, protein and lactose percentages, respectively. Heritabilities of udder type traits agreed with findings of du Toit, van Wyk, and Maiwashe (2012) for South African Jersey breed and were slightly lower than estimates of Gengler, Wiggans, Wright, Norman, and Wolfe (1997), who reported heritabilities of udder traits in the range from 0.20 to 0.30 . Moreover, heritability estimates of udder type traits of this study were consistent with those reported by Cassandro, Battagin, Penasa, and De Marchi (2015) for Holstein Friesian and Dal Zotto et al. (2007) for Brown Swiss cows.

\section{2 | Correlations}

\subsubsection{Correlations between SCC traits}

Genetic correlations between alternative SCC traits have been reported only for Holstein cows (Bobbo et al., 2018; Urioste, Franzén, Windig, \& Strandberg, 2012; Windig et al., 2010) and thus findings of this study could be compared only with the existing literature. Overall, our results demonstrated strong genetic correlations between SCC traits, with the only exception of SCS_SD, which was moderately correlated with traits indicating the presence of SCC peaks in the lactation (i.e. Infection and Severity) and uncorrelated with traits expressing mean values (SCS_LM and SCS_150). Similar results were obtained by Koeck et al. (2012a) and Bobbo et al. (2018) in Holsteins, with the exception of SCS_SD, which was moderately positively correlated also with SCS mean values. Different findings could be explained by different characteristics of the two breeds. In fact, results reported by Bobbo et al. (2018) suggested that Holstein cows had lower SCS, both when averaged over the whole lactation or over the first 150 DIM, compared with Jersey cows: 2.86 vs. 3.09 for SCS_LM and 2.66 vs. 3.01 for SCS_150, respectively. However, compared to Jersey, Holsteins had greater SCS_SD (1.29 vs. 1.10$)$, higher Infection ( $47 \%$ vs. $43 \%$ ) and greater Severity $(14 \%$ vs. $11 \%)$. The apparent discrepancies between the two dairy breeds might also be related to the uncertainty of the estimates, given the
TAB LE 3 Genetic correlations (above diagonal; SE within parentheses) and phenotypic correlations (below diagonal) of lactation-mean somatic cell score (SCS_LM) and alternative somatic cell count (SCC) traits of first-parity Jersey cows $(n=8,124)$

\begin{tabular}{llllll} 
Trait & SCS_LM & SCS_150 & SCS_SD & Infection & Severity \\
\hline SCS_LM & - & $0.986(0.014)$ & $0.000(0.207)$ & $0.808(0.074)$ & $0.846(0.055)$ \\
\hline SCS_150 & 0.894 & - & $-0.027(0.222)$ & $0.783(0.098)$ & $0.802(0.083)$ \\
\hline SCS_SD & 0.215 & 0.186 & - & $0.589(0.149)$ & $0.521(0.171)$ \\
Infection & 0.565 & 0.519 & 0.610 & - & $0.989(0.014)$ \\
Severity & 0.704 & 0.628 & 0.454 & 0.702 & -
\end{tabular}

SCS_150: average SCS in early lactation (5-150 days in milk); SCS_SD: standard deviation of SCS of the entire lactation; Infection: a binary trait indicating absence (0) or presence (1) of at least one test-day SCC above 400,000 cells/ml; Severity: ratio of the number of test-day SCC above $400,000 \mathrm{cells} / \mathrm{ml}$ to total number of test-days in the lactation. 


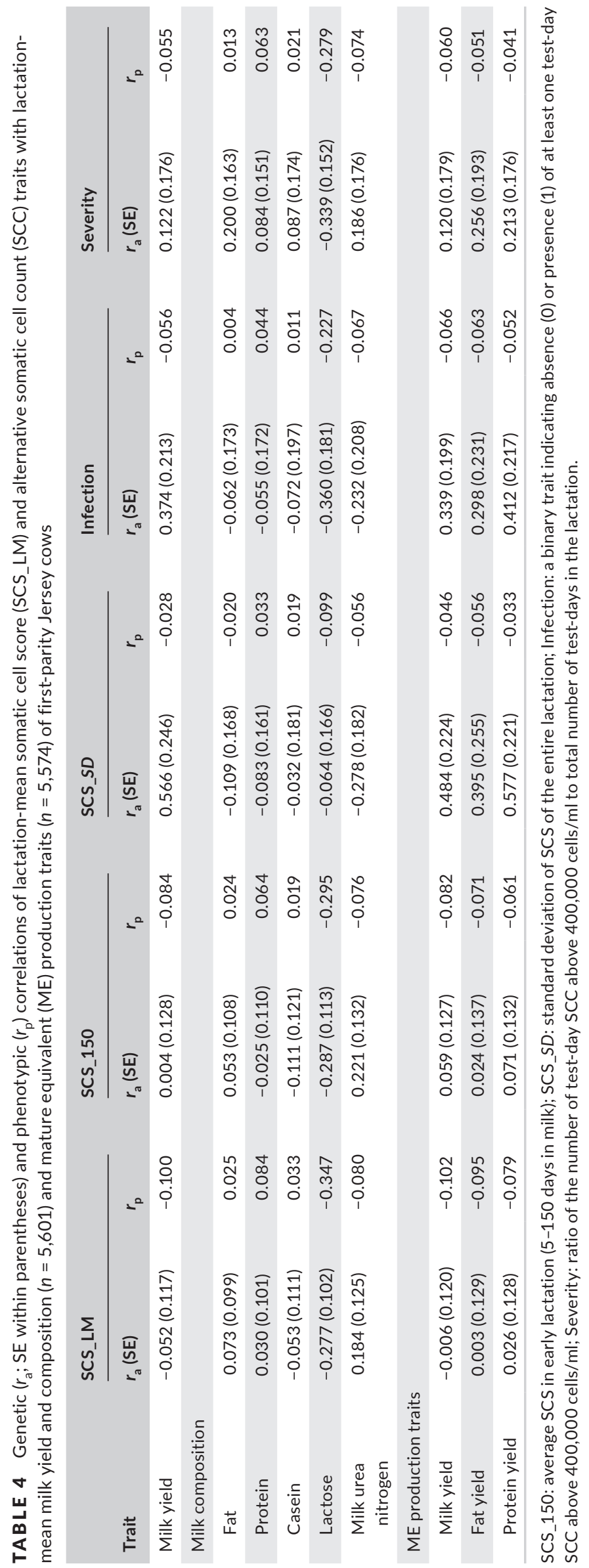




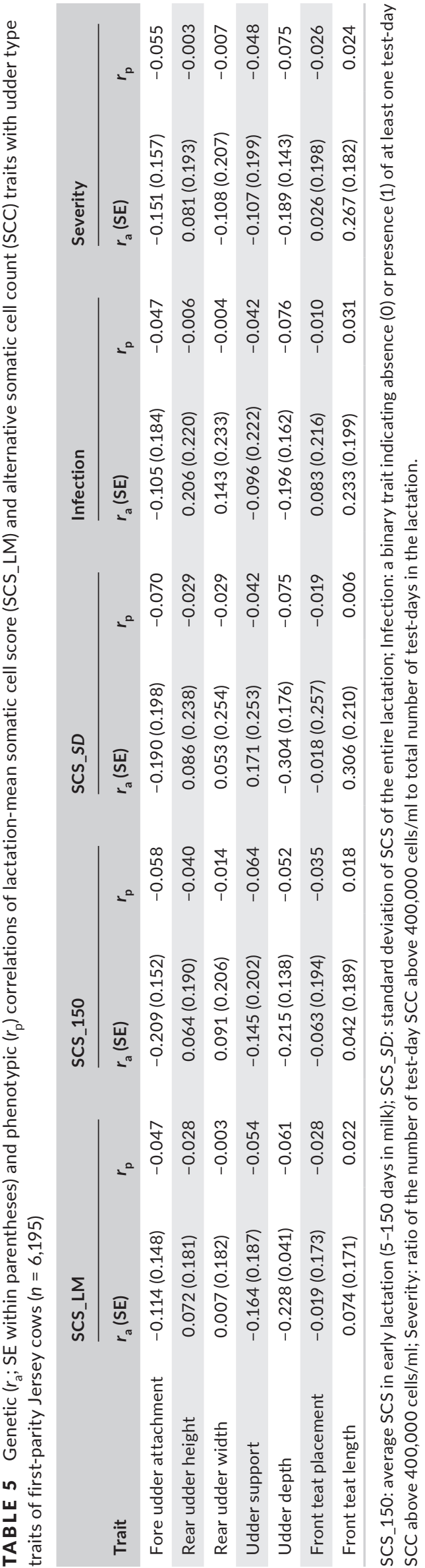

large standard errors associated with estimates of genetic correlations in this study. One of the strategies to increase the precision of such genetic estimates would be to increase the size of the dataset analysed, but this would require more years of data collection given the small size of Jersey population in Italy. Genetic correlations between SCS_LM and alternative SCC traits of this study confirmed the strong associations reported by de Haas et al. (2008) between lactation average SCS and new SCC traits (SCS in early lactation, presence of at least one TD SCC > 150,000 cells/ml and proportion of TD SCC > 150,000 cells $/ \mathrm{ml}$ ).

\subsubsection{Correlations of SCC traits with lactation- mean milk yield and composition, and ME milk production traits}

To the best of our knowledge, genetic correlations between alternative SCC traits and milk production and composition traits on Jersey cattle have been reported for the first time in this study (Table 4). Thus, comparisons with the existing literature can be made considering the standard TD or lactation-average SCC or SCS. Our findings confirmed the association between high SCC and reduced milk production (weak negative phenotypic correlation with all SCC traits) and may suggest that high-producing cows are more susceptible to variation in SCC than cows with intermediate or low production (positive genetic correlation with SCS_SD and Infection). This hypothesis was supported also by Haile-Mariam, Bowman, and Goddard (2001) and Koivula, Mäntysaari, Negussie, and Serenius (2005), who observed unfavourable genetic correlations between SCC and milk production in first-parity Australian Holsteins and Finnish Ayrshires, respectively. Positive genetic correlations of SCS with milk yield and composition traits were estimated by Carlén, Strandberg, and Roth (2004) in Swedish Holstein cows; those authors reported genetic correlations of $0.22,0.17$ and 0.23 between lactation-average SCS, calculated as the arithmetic mean of monthly TD SCC from 5 to 150 DIM, and 305-day milk, fat and protein yield, respectively. In this study, lactose percentage had the strongest correlations with SCC traits, negative both at phenotypic and genetic level. Therefore, as expected, increased milk SCC was associated with a reduction in lactose content. Negative genetic (phenotypic) correlations of $-0.20(-0.23)$ and $-0.44(-0.24)$ between lactose percentage and SCS were reported also by Miglior et al. (2007) in Canadian Holsteins and Stoop, Bovenhuis, and van Arendonk (2007) in Dutch Holstein-Friesians, respectively. Moreover, Visentin et al. (2017b) estimated an average genetic correlation of -0.28 between lactose percentage and SCS in Irish dairy cows from several breeds, including Jersey, and crossbreds.

\subsection{3 | Correlations between SCC traits and udder type traits}

Genetic correlations between SCC and udder type traits were mostly weak and not different from zero, due to the small size of the subset. Nevertheless, our estimates highlighted that cows with deep udders, 
loose attachments, weak ligaments and long teats were more susceptible to an increase of SCC in milk, as suggested by the negative genetic correlations of alternative SCC traits with udder depth, fore udder attachment and udder support, and the positive genetic correlations with front teat length (Table 5). Interestingly, our findings confirmed previous results of Koeck, Miglior, Kelton, and Schenkel (2012b) on alternative SCC traits in Canadian Holsteins. In fact, those authors reported moderate negative genetic correlations between alternative SCC traits (mean SCS in early lactation, standard deviation of SCS and presence of at least one TD SCC above 500,000 cells $/ \mathrm{ml}$ ) and udder type traits (udder depth and fore udder attachment), in the range from -0.31 (standard deviation of SCS and udder depth) to -0.15 (standard deviation of SCS and fore udder attachment). Results of this study agreed with previous findings of Dube, Dzama, Banga, and Norris (2009) in Jersey cattle; those authors suggested that deep, loosely attached udders were associated with high SCS, as they are possibly at greater risk of injury and contamination due to closeness to the ground. Moreover, Rogers, Hargrove, Lawlor, and Ebersole (1991) reported that longer teats were more prone to injury during handling and milking. An increased risk of subclinical mastitis in Jersey cows with udders close to the ground and long front teats have been observed also by Akdag, Ugurlu, Gurler, Teke, and Kocak (2017).

\section{5 | CONCLUSIONS}

Alternative SCC traits analysed in this study expressed exploitable genetic variation for breeding purposes. Estimated genetic correlations of alternative SCC traits with milk production, fat and protein yields, and fore udder attachment, udder support and udder depth, which are traits included in the selection index of Italian Jersey breed, will help to identify the best SCC traits to be used as indicators of intramammary infection and thus for selection to improve udder health. Also, selection accuracy for mastitis resistance may be increased by combining udder type and SCC traits into an udder health index, using genetic parameters estimated in this study. Further work is required to assess the association between the new SCC traits and clinical mastitis events.

\section{ACKNOWLEDGEMENT}

This study was supported by "Latteco project", sottomisura 10.2 of the PSRN-Biodiversity 2014-2020 and by the University of Padova (Ricerca Scientifica fondi DOR - 2018, project DOR1899548/18, Italy).

\section{ORCID}

Tania Bobbo iD https://orcid.org/0000-0003-0328-8903

Mauro Penasa (iD https://orcid.org/0000-0001-9984-8738

\section{REFERENCES}

Akdag, F., Ugurlu, M., Gurler, H., Teke, B., \& Kocak, O. (2017). The relationships between udder traits and milk yield, milk composition, and subclinical mastitis in Jersey cows. Large Animal Review, 23(6), 203-209.

Ali, A. K. A., \& Shook, G. E. (1980). An optimum transformation for somatic cell concentration in milk. Journal of Dairy Science, 63(3), 487490. https://doi.org/10.3168/jds.S0022-0302(80)82959-6

Biffani, S., Samoré, A. B., \& Canavesi, F. (2003). Breeding strategies for the Italian Jersey. Italian Journal of Animal Science, 2(Suppl. 1), 79-81. https://doi.org/10.4081/ijas.2003.11675921

Bobbo, T., Penasa, M., Finocchiaro, R., Visentin, G., \& Cassandro, M. (2018). Alternative somatic cell count traits exploitable in genetic selection for mastitis resistance in Italian Holsteins. Journal of Dairy Science, 101, 10001-10010. in press. https://doi.org/10.3168/ jds.2018-14827

Campos, M. S., Wilcox, C. J., Becerril, C. M., \& Diz, A. (1994). Genetic parameters for yield and reproductive traits of Holstein and Jersey cattle in Florida. Journal of Dairy Science, 77(3), 867-873. https://doi. org/10.3168/jds.S0022-0302(94)77021-1

Carlén, E., Strandberg, E., \& Roth, A. (2004). Genetic parameters for clinical mastitis, somatic cell score, and production in the first three lactations of Swedish Holstein cows. Journal of Dairy Science, 87(9), 3062-3070. https://doi.org/10.3168/jds.S0022-0302(04)73439-6

Cassandro, M., Battagin, M., Penasa, M., \& De Marchi, M. (2015). Short communication: Genetic relationships of milk coagulation properties with body condition score and linear type traits in HolsteinFriesian cows. Journal of Dairy Science, 98(1), 685-691. https://doi. org/10.3168/jds.2014-8153

Dal Zotto, R., De Marchi, M., Dalvit, C., Cassandro, M., Gallo, L., Carnier, P., \& Bittante, G. (2007). Heritabilities and genetic correlations of body condition score and calving interval with yield, somatic cell score, and linear type traits in Brown Swiss cattle. Journal of Dairy Science, 90(12), 5737-5743. https://doi.org/10.3168/jds.2007-0280

de Haas, Y., Ouweltjes, W., ten Napel, J., Windig, J. J., \& de Jong, G. (2008). Alternative somatic cell count traits as mastitis indicators for genetic selection. Journal of Dairy Science, 91(6), 2501-2511. https:// doi.org/10.3168/jds.2007-0459

du Toit, J., van Wyk, J. B., \& Maiwashe, A. (2012). Relationships between functional herd life and conformation traits in the South African Jersey breed. South African Journal of Animal Science, 42(1), 47-54. https://doi.org/10.4314/sajas.v42i1.6

Dube, B., Dzama, K., Banga, C. B., \& Norris, D. (2009). An analysis of the genetic relationship between udder health and udder conformation traits in South African Jersey cows. Animal, 3(4), 494-500. https:// doi.org/10.1017/S175173110800390X

Finocchiaro, R., Visentin, G., Penasa, M., van Kaam, J. B. C. H. M., Marusi, M., Civati, G., \& Cassandro, M. (2018). Alternative use of somatic cells counts in genetic selection for mastitis resistance: A new estimated breeding value for Italian Holstein breed. Interbull Bulletin, 53, 31-33.

Gengler, N., Wiggans, G. R., Wright, J. R., Norman, D., \& Wolfe, C. W. (1997). Estimation of (co)variance components for Jersey type traits using a repeatability model. Journal of Dairy Science, 80(8), 18011806. https://doi.org/10.3168/jds.S0022-0302(97)76114-9

Green, M. J., Green, L. E., Schukken, Y. H., Bradley, A. J., Peeler, E. J., Barkema, H. W., ... Medley, G. F. (2004). Somatic cell count distributions during lactation predict clinical mastitis. Journal of Dairy Science, 87(5), 1256-1264. https://doi.org/10.3168/jds. S0022-0302(04)73276-2

Haile-Mariam, M., Bowman, P. J., \& Goddard, M. E. (2001). Genetic and environmental correlations between test-day somatic cell count and milk yield traits. Livestock Production Science, 73(1), 1-13. https://doi. org/10.1016/S0301-6226(01)00232-9 
Koeck, A., Miglior, F., Kelton, D. F., \& Schenkel, F. S. (2012a). Alternative somatic cell count traits to improve mastitis resistance in Canadian Holsteins. Journal of Dairy Science, 95(1), 432-439. https://doi. org/10.3168/jds.2011-4731

Koeck, A., Miglior, F., Kelton, D. F., \& Schenkel, F. S. (2012b). Short communication: Genetic parameters for mastitis and its predictors in Canadian Holsteins. Journal of Dairy Science, 95(12), 7363-7366. https://doi.org/10.3168/jds.2012-5648

Koivula, M., Mäntysaari, E. A., Negussie, E., \& Serenius, T. (2005). Genetic and phenotypic relationship among milk yield and somatic cell count before and after clinical mastitis. Journal of Dairy Science, 88(2), 827833. https://doi.org/10.3168/jds.S0022-0302(05)72747-8

Martin, P., Barkema, H. W., Brito, L. F., Narayana, S. G., \& Miglior, F. (2018). Symposium review: Novel strategies to genetically improve mastitis resistance in dairy cattle. Journal of Dairy Science, 101(3), 2724-2736. https://doi.org/10.3168/jds.2017-13554

Miglior, F., Sewalem, A., Jamrozik, J., Bohmanova, J., Lefebvre, D. M., \& Moore, R. K. (2007). Genetic analysis of milk urea nitrogen and lactose and their relationships with other production traits in Canadian Holstein cattle. Journal of Dairy Science, 90(5), 2468-2479. https:// doi.org/10.3168/jds.2006-487

Missanjo, E., Imbayarwo-Chikosi, V., \& Halimani, T. (2013). Estimation of genetic and phenotypic parameters for production traits and somatic cell count for Jersey dairy cattle in Zimbabwe. ISRN Veterinary Science, 2013. Article ID 470585. https://doi.org/10.1155/2013/470585

Neumaier, A., \& Groeneveld, E. (1998). Restricted maximum likelihood estimation of covariances in sparse linear models. Genetics Selection Evolution, 30, 3-26. https://doi.org/10.1186/1297-9686-30-1-3

Rogers, G. W., Hargrove, G. L., Lawlor, T. J. Jr, \& Ebersole, J. L. (1991). Correlations among linear type traits and somatic cell counts. Journal of Dairy Science, 74(3), 1087-1091. https://doi.org/10.3168/jds. S0022-0302(91)78259-3

Roman, R. M., Wilcox, C. J., \& Martin, F. G. (2000). Estimates of repeatability and heritability of productive and reproductive traits in a herd of Jersey cattle. Genetics and Molecular Biology, 23(1), 113-119. https://doi.org/10.1590/S1415-47572000000100021

Roveglia, C., Niero, G., Penasa, M., Finocchiaro, R., Marusi, M., LopezVillalobos, N., \& Cassandro, M. (2019). Phenotypic analysis of milk composition, milk urea nitrogen and somatic cell score of Italian Jersey cattle breed. Italian Journal of Animal Science (In press). https:// doi.org/10.1080/1828051X.2018

Ruegg, P. L. (2017). A 100-Year Review: Mastitis detection, management, and prevention. Journal of Dairy Science, 100(12), 10381-10397. https://doi.org/10.3168/jds.2017-13023

Sneddon, N. W., Lopez-Villalobos, N., Hickson, R. E., \& Shalloo, L. (2012). Genetic parameters for lactose and its relationship with concentrations and ratios of other milk components. Proceedings of the New Zealand Society of Animal Production, 72, 76-80.

Stocco, G., Cipolat-Gotet, C., Bobbo, T., Cecchinato, A., \& Bittante, G. (2017). Breed of cow and herd productivity affect milk composition and modeling of coagulation, curd firming, and syneresis. Journal of Dairy Science, 100(1), 129-145. https://doi.org/10.3168/ jds.2016-11662

Stoop, W. M., Bovenhuis, H., \& van Arendonk, J. A. M. (2007). Genetic parameters for milk urea nitrogen in relation to milk production traits. Journal of Dairy Science, 90(4), 1981-1986. https://doi.org/10.3168/ jds.2006-434

Urioste, J. I., Franzén, J., \& Strandberg, E. (2010). Phenotypic and genetic characterization of novel somatic cell count traits from weekly or monthly observations. Journal of Dairy Science, 93(12), 5930-5941. https://doi.org/10.3168/jds.2010-3301

Urioste, J. I., Franzén, J., Windig, J. J., \& Strandberg, E. (2012). Genetic relationships among mastitis and alternative somatic cell count traits in the first 3 lactations of Swedish Holsteins. Journal of Dairy Science, 95(6), 3428-3434. https://doi. org/10.3168/jds.2011-4739

Visentin, G., De Marchi, M., Berry, D. P., McDermott, A., Fenelon, M. A., Penasa, M., \& McParland, S. (2017a). Factors associated with milk processing characteristics predicted by mid-infrared spectroscopy in a large database of dairy cows. Journal of Dairy Science, 100(4), 3293-3304. https://doi.org/10.3168/jds.2016-12028

Visentin, G., McParland, S., De Marchi, M., McDermott, A., Fenelon, M. A., Penasa, M., \& Berry, D. P. (2017b). Processing characteristics of dairy cow milk are moderately heritable. Journal of Dairy Science, 100(8), 6343-6355. https://doi.org/10.3168/ jds.2017-12642

Windig, J. J., Ouweltjes, W., ten Napel, J., de Jong, G., Veerkamp, R. F., $\&$ de Haas, Y. (2010). Combining somatic cell count traits for optimal selection against mastitis. Journal of Dairy Science, 93(4), 1690-1701. https://doi.org/10.3168/jds.2009-2052

How to cite this article: Bobbo T, Roveglia C, Penasa M, Visentin G, Finocchiaro R, Cassandro M. Genetic relationships of alternative somatic cell count traits with milk yield, composition and udder type traits in Italian Jersey cows. Anim Sci J. 2019;90:808-817. https://doi.org/10.1111/asj.13204 